\title{
Economic Analysis of Integrated Crop Management Practices of 'Navel' Oranges
}

\author{
Etaferahu Takele ${ }^{1}$ \\ Soil and Environmental Sciences Department, University of California, Riverside, CA 92521
}

John A. Menge ${ }^{2}$

Plant Pathology Department, University of California, Riverside, CA 92521

John E. Pehrson, Jr. ${ }^{3}$

Lindcove Research and Extension Center, 22963 Carson Ave., Exeter, CA 93211

Jewell L. Meyer ${ }^{4}$

Soil and Environmental Sciences Department, University of California, Riverside, CA 92521

Charles W. Coggins, Jr. ${ }^{5}$

Botany and Plant Sciences Department, University of California, Riverside, CA 92521

Mary Lu Arpaia ${ }^{6}$

Botany and Plant Sciences Department, University of California, Riverside, CA 92521

J. Daniel Hare
Entomology Department, University of California, Riverside, CA 92521

Darwin R. Atkin ${ }^{8}$

Lindcove Research and Extension Center, 22943 Carson Ave., Exeter, CA 93211

Carol Adams ${ }^{9}$

Statistics Department, University of California, Riverside, CA 92521

Additional index words. citrus sinensis, costs, integrated practices, productivity, returns

\begin{abstract}
The effect of various integrated crop management practices on productivity (fruit yield, grade, and sire) and returns of 'Washington Navel' oranges [Citrus sinensis (L.) Osbeck] was determined in the San Joaquin Valley of California. Seventy-two combinations of treatments comprised of three irrigation levels $[80 \%, 100 \%$, and $120 \%$ evapotranspiration demand (ETc)], three $\mathrm{N}$ fertilizer levels (low, medium, and high based on $2.3 \%, 2.5 \%$, and $2.7 \%$ leaf $\mathrm{N}$, respectively), gibberellic acid $( \pm)$, miticide $( \pm)$, and fungicide-nematicide $( \pm)$ were included in the analysis. Using a partial budgeting procedure, returns after costs were calculated for each treatment combiition. Costs of treatments, harvesting, packing, and processing were subtracted from the value of the crop. The value of the crop was calculated as the sum of returns of crop in each size and grade category. The overall result indicated that returns after costs were higher for the + fungicidenematicide treatment and also were generally more with increased irrigation. The combination of $120 \%$ ETc, +fungicidenematicide, medium or high $\mathrm{N}$, -miticide, and -gibberellin showed the highest return of all treatment combinations. Second highest returns were obtained with high $\mathrm{N}$ or with miticide and gibberellin used together.
\end{abstract}

Several extensive studies evaluating the effect of certain inputs on citrus growth and productivity have been conducted in California and throughout the world. Some of those studies included irrigation (Marsh, 1973), fertilization (Embleton et al., 1978), and the use of various growth regulators (Coggins and Hield, 1968).

Received for publication 13 July 1992. Accepted for publication 9 Apr. 1993. Supported in part by grants from the Univ. of California Statewide Integrated Pest Management Project and the Citrus Research Board. Mention of a trademark, proprietary product, or vendor does not constitute a guarantee or warranty of the product by the Univ. of California and does not imply its approval to the exclusion of other products or vendors that may be suitable. The cost of publishing this paper was defrayed in part by the payment of page charges. Under postal regulations, this paper therefore must be hereby marked advertisement solely to indicate this fact. ${ }^{1}$ Extention farm management specialist.

${ }^{2}$ Plant pathologist.

${ }^{3}$ Extension subtropical horticulture specialist, Retired.

${ }^{4}$ Extension irrigation and soils specialist, Emeritus.

${ }^{5}$ Plant physiologist.

${ }^{6}$ Extension subtropical horticulture specialist.

${ }^{7}$ Associate entomologist.

${ }^{8}$ Staff research associate.

${ }^{9}$ Principal statistician.
However, no previous study has addressed the interactive effects of such treatments on productivity and grower returns. The objective of this study was to do so in a 'Washington Navel' orange grove in which the interaction of contemporary grove management practices would be studied in one large-scale field experiment. We wanted to identify practices that maximize productivity and profits. We also calculated the effects of varied water prices on profitability when various management practices were used.

\section{Materials and Methods}

A multidisciplinary, multiyear experiment was initiated in 1985 in the southern San Joaquin Valley of California on a 35-year-old parent 'Washington Navel' orange grove grown on rough lemon (Citrus jambhiri Lush) rootstock. The design was a randomized complete block with split-split-split plots consisting of a $3 \times 2 \times 2 \times 3 \times 2$ factorial treatment design; i.e., three irrigation treatments $[80 \%, 100 \%$, and $120 \%$ of calculated daily evapotranspiration demand (ETc)], two fungicide-nematicide treatments $( \pm)$, two miticide treatments $( \pm)$, three $\mathrm{N}$ fertilizer levels $(\mathrm{N} 1=$ low, $\mathrm{N} 2$ 
$=$ medium, and N3 = high), and two growth regulator treatments $( \pm)$. Irrigation levels served as main plots, fungicide-nematicide treatments were the subplots, miticide treatments were the sub-subplots, and $\mathrm{N} \times$ gibberellic acid treatments were the sub-sub-subplots. There were 288 trees in four blocks, with one tree per block in each of the 72 treatment combinations.

Many university personnel were involved in this project, and the treatments were applied and effects were examined regularly. Complete descriptions of the various university personnel involved have been published (Menge et al., 1990). A description of the McKellar experimental plot and treatment protocols has also been published (Hare et al., 1989a). Briefly, the irrigation system included low-volume nonrotating micro-sprinklers (one sprinkler per tree) on individual, pressure-regulated water lines, with each line serving six trees. Improved water filters were installed and the system was monitored yearly to provide $90 \%$ uniformity. Each irrigation level was used on two adjacent rows of trees (12 data trees per row). A buffer row of trees with an identical irrigation level bordered each data row. Then another row was treated with intermediate ETcs of $90 \%$ (separating the $80 \%$ and $100 \%$ irrigation level) and $110 \%$ (separating the $100 \%$ and $120 \%$ irrigation levels). This means there were three buffer rows between data rows. This design was used to ensure that data trees were not being affected by irrigation from neighboring rows and also to create sufficient distance with buffer rows so that root-growth overlap would not interfere with treatments.

The choice of ETc levels- $80 \%=$ low, $100 \%=$ medium, and $120 \%=$ high-was based on their expected direct effects on photosynthesis and yield (Hoare and Barrs, 1974; Marsh, 1973). All of the trees were irrigated simultaneously for $24 \mathrm{~h}$. This approach enabled us to meet scheduling requirements imposed by the irrigation district and availability of farm labor. The difference in quantity of water among irrigation treatments was regulated by the water flow rate by adjusting the operating pressure $(110 \mathrm{kPa}$ for $80 \%, 135$ to $165 \mathrm{kPa}$ for $100 \%$, and 207 to $221 \mathrm{kPa}$ for $120 \%$ ). Irrigation schedules were varied according to ETc (determined from California Dept. of Water Resources weekly reports on crop water use issued for the southern San Joaquin Valley) and any rainfall since the previous irrigation. For instance, in April, irrigation schedules may be at 7- to 8-day intervals; whereas, in July and August, more frequent schedules, such as 3- to 4-day intervals, are required. The total amount of water applied per annum per hectare was $\approx 610$ ha-mm at $80 \%$ ETc, 760 ha-mm at $100 \%$ ETc, and 920 ha$\mathrm{mm}$ at $120 \%$ ETc.

Water movement and extraction from the soil were monitored by 13 soil water monitoring stations, each with two tensiometers, one 30 and the other $60 \mathrm{~cm}$ deep. While tensiometers show the vertical profile of moisture, neutron probe measurements provided additional data on lateral and vertical volumetric moisture distribution. During spring irrigations, water readily filled the soil profile; however, by midsummer, infiltration slowed such that shallow lateral wetting became the dominant form of water replenishment. External manifestations of water stress (leaf wilting) were observed rarely, except in the $80 \%$ ETc treatment.

Half of the experimental trees (each pair of rows divided halfway down the row) received fungicide-nematicide treatments through irrigation water using pesticide injectors (Garabedian and Van Gundy, 1985). Methyl $N^{\prime} ' N$ dimethyl- $N$ [(methyl carbamoyl) oxy]-1-thioaxamimidate (oxamyl) (Vydate L; Du Pont, Wilmington, Del.) was applied monthly from May through October and $N$ - (2,6-dimethylphenyl)- $N$ - (methoxyacetyl)-DL-alanine methyl ester (metalayxl) (Ridomil 2E; CIBA-GEIGY, Greensboro, N.C.) was applied at the rate of $58 \mathrm{ml} /$ tree twice each year, once in June and again in September. We applied a total amount of 22.28 liters of oxamyl and 26.68 liters of metalayxl per hectare per annum.

Thrip and mite monitoring started in 1986. One-fourth of each pair of rows was sprayed with oxythioquinox (Morestan 25 wettable powder; Mobay Corp., Kansas City, Mo.) starting in 1987 (Hare et al., 1989b). Oxythioquinox was applied at an annual rate of $11.2 \mathrm{~kg} \cdot \mathrm{ha}^{-1}$ in April before trees bloomed and before citrus red mite population expanded. One tree from each irrigation, fungicide-nematicide, miticide, and fertilization combination received a growth-regulator application. Gibberellic acid $\left(\mathrm{GA}_{3}\right)$ (Pro-Gibb 3.91\%; Abbott Laboratories, North Chicago, Ill.) was applied yearly since 1985 at $100 \mathrm{~g}$ a.i./ha. All other treatments, including insecticides, 2-4D to reduce fruit drop, copper-lime treatments for brown rot control on fruit, herbicides for weed control, gypsum $\left(\mathrm{CaSO}_{4} 2 \mathrm{H}_{2} \mathrm{O}\right)$ to improve soil water penetration, $\mathrm{Zn}, \mathrm{Mn}$, and $\mathrm{Mg}\left(\mathrm{NO}_{3}\right)_{2}$ nutritional sprays, were applied uniformly to all trees as needed.

Nitrogen fertilizer was applied to individual trees during January and March each year. The $\mathrm{N}$ application in each of the three treatments varied from year to year (Hare et al., 1990) and was a mixture of $45 \%$ ammonium nitrate and $55 \%$ urea. Nitrogen fertilizer was applied to maintain consistent leaf analyses; the goal for $\mathrm{N}$ was low, 2.3\% (N1); medium, 2.5\% (N2); and high, 2.7\% (N3). The average actual yearly amount of $\mathrm{N}$ applied from 1985 to 1990 was $82 \mathrm{~kg} \cdot \mathrm{ha}^{-1}$ for $\mathrm{N} 1,140 \mathrm{~kg} \cdot \mathrm{ha}^{-1}$ for N2, and $195 \mathrm{~kg} \cdot \mathrm{ha}^{-1}$ for N3.

The economic analysis was done for 1987-90. Although the commercial pack-out data were used for 1987-89 to examine the treatment effects taken two at a time (irrigation $\times$ fungicidenematicide in 1987 , fertilization $\times$ gibberellin in 1988 , fertilization $\times$ miticide in 1989, and fungicide-nematicide $\times$ miticide in 1990), in 1990, laboratory data were used to look at productivity, returns, and cost effects of all five treatment factors and their interactions.

All trees for which data were collected were harvested during the same week in March 1990, approximating a late-season harvest. Productivity (fruit yield, size, and grade) was measured for each tree. Because a commercial packout requires fruit from 40 to 50 trees, it was not possible to have separate packing statements for individual treatments. Therefore, we designed a small-scale fruit grading procedure, which used a sample of 100 fruit from each tree. For this sample, fruit were picked around the circumference of the tree from a height of 0 to $2 \mathrm{~m}$ and from east and west sides of the tree starting $2 \mathrm{~m}$ from the ground and continuing to the top of the tree. Pickers were instructed to pick more heavily in areas with more fruit and to pick lightly from areas with little fruit. For the grading process, our personnel were trained by a commercial packinghouse manager to classify fruit into three grades, [first, second (with trade names of Sunkist and Choice, respectively), and juice], and eight size classifications. In this fashion, data were collected for each of the 288 data trees.

The economic analysis used a partial budgeting procedure in which all the costs of treatment, harvesting, packing, and processing were subtracted from the value of the crop. The treatment costs included the material and application of fertilizer, fungicidenematicides, gibberellin, miticide, and water. The annual amount of material of each input was multipied by its annual average price. Application costs were extracted from the owner's production costs (Takele and Pehrson, 1989) and from the Central Valley Regional Cost Study for Tulare County (O'Connell et al., 1987). Interest on operating capital was also included. Because water costs vary depending on elevation and location, returns were evaluated at various water prices.

Harvesting and marketing costs are functions of yield and, there- 
fore, vary with the level of productivity. Costs of picking, hauling, packing, marketing, advertising, and handling products were based on the California-Arizona Citrus League survey (1990) for the 1988-91 seasons.

The crop value was calculated as the sum of the returns of crop for each size and grade category using the following formula: $\mathrm{R}=$ $8 \Sigma(i=1)\left(p_{i 1} q_{i 1}+p_{i 2} q_{i 2}\right)+p_{i} q_{i}$, where $R$ is the total return (TR) (crop value); $p_{i 1}$ is the price of the ith size and Grade 1 crop; $p_{i 2}$ is the price of the ith size and Grade 2 crop; $\mathrm{q}_{\mathrm{i} 1}$ is the quantity of the ith size and grade 1 crop; $q_{i 2}$ is the quantity of the ith size and Grade 2 crop; $p_{j}$ is the price of Juice, and $\mathrm{q}_{\mathrm{j}}$ is the quantity of crop juiced.

Annual weighted average prices for San Joaquin Valley 'Navel' oranges were used for each size and grade group. During 1984-90, Grade 1 prices averaged $48 \%$ higher than Grade 2 prices. Larger fruit also received a higher price than smaller fruit during the experiment. Juice value was positive in all years except 1987. Because the packinghouse first sorts and sizes the crop into fresh and juice-quality grades, then removes certain sizes from the fresh grade to juice, we adjusted the value of the crop and grower returns after costs accordingly in our analysis. It should be noted that this is a partial budget analysis, because costs affecting all treatments equally, including 2-4D, copper lime, gypsum, herbicides, $\mathrm{Zn}$, and Mn, were not accounted for in the economic analysis. Therefore the returns after costs are not net returns and are referred to as partial net returns (PNRs) in the analysis.

The PNRs are calculated as follows: $\mathrm{PNR}=\mathrm{R}-$ costs (water + $\mathrm{F}-\mathrm{N}+\mathrm{M}+\mathrm{N}+\mathrm{G})-\mathrm{H}_{\mathrm{c}}(\mathrm{Y})-\mathrm{P}_{\mathrm{c}}$ (packed fruit) $-\mathrm{PR}_{\mathrm{c}}$ (juiced fruit), where $\mathrm{R}$ is TRs; F - N, M, N, and $\mathrm{G}$ are fungicide-nematicide, miticide, $\mathrm{N}$, and gibberellin, respectively; $\mathrm{H}_{\mathrm{c}}$ is harvesting cost; $\mathrm{Y}$ is total yield; $\mathrm{P}_{\mathrm{c}}$ is packing cost; and $\mathrm{PR}_{\mathrm{c}}$ is product handling cost.

Multiple regressions of dependent variables including productivity (yield measured in cartons, grade measured by percentage Grade 1, and size measured by percentage $225.4 \mathrm{~mm}$ fruit per tree), crop value (TRs), and PNRs (crop value less costs of treatments) were run on 1985 pretreatment yield, irrigation line position, tree size, tree evaluation (appearance and vigor scaled 1 to 6 , where $1=$ best - only trees with a rating of 1 to 3 were included in the experiment), and presence or absence of hardpan. A two-step multiple covariance analysis was performed. First, the significant effects of these multiple regressions were removed from the dependent variables to adjust for possible biases and to reduce the magnitude of error terms for testing treatment factors and interactions. Then analyses of variance were done for the adjusted biological productivity measures (yield, grade, and size), economic measures of TRs, and the PNRs. The statistical analyses serve to point out, in this complicated design, statistically significant effects, which involved five main factors (irrigation, fungicide-nematicide, $\mathrm{N}$ fertilizer, miticide, and gibberellin). Means were compared using $\mathrm{F}$ values.

\section{Results}

The main effect means and statistical significance of productivity (yield, percentage Grade 1, and percentage size $225.4 \mathrm{~mm}$ ), TRs, and PNRs of the 1990 harvest are summarized in Table 1. Two interactions showed significance at $P \leq 0.01$ or better on one or more of the measures of productivity and returns. The means and statistical significance of productivity and the TRs and PNRs of these interactions (irrigation $\times \mathrm{N}$ and miticide $\times$ gibberellin) are summarized in Tables 2 and 3, respectively. Of the remaining 24 interactions, four had significance at $P \leq 0.05$ on one of the five measures and two had significance at $P \leq 0.05$ on two measures. The trends shown in these low-level-significance interactions did not show economic importance and are not presented here.

Irrigation $\times \mathrm{N}$ main and interactive effects

Yield. There was no significant effect of irrigation on yield, but yield was significantly higher with increased $N$ (Table 1). The interactive effect showed significant increase in yield with increased irrigation for $\mathrm{N} 2$ and $\mathrm{N} 3$ but no effect of irrigation for N1 (significant irrigation linear $\times \mathrm{N}$ linear interaction) (Table 2).

Grade. The $100 \%$ ETc level had a higher level of Grade 1 fruit (significant quadratic effect), but increased $\mathrm{N}$ resulted in signifi-

Table 1. Main effects of treatment factors on 'Navel' orange average yield percentage Grade 1, percentage size $\geq 25.4 \mathrm{~mm}$ fruit per tree, total returns (TRs), and partial net returns (PNRs), 1990.

\begin{tabular}{|c|c|c|c|c|c|}
\hline Treatment & $\begin{array}{c}\text { Yield } \\
\mathrm{kg} / \text { tree }\end{array}$ & $\begin{array}{c}\text { Grade } \\
1 \\
(\%)\end{array}$ & $\begin{array}{c}\text { Size } \\
\geq 25.4 \\
(\%)\end{array}$ & $\begin{array}{c}\text { TRs } \\
\text { (\$/tree) }\end{array}$ & $\begin{array}{c}\text { PNRs } \\
(\$ / \text { tree })\end{array}$ \\
\hline \multicolumn{6}{|c|}{ Irrigation (\% ETc) } \\
\hline 120 & 228 & 50.5 & 14.1 & 92.59 & 44.22 \\
\hline 100 & 212 & 52.4 & 10.0 & 85.24 & 40.07 \\
\hline \multirow[t]{2}{*}{80} & 212 & 48.9 & 5.4 & 77.75 & 35.36 \\
\hline & NS & $Q^{*}$ & $\mathrm{~L}^{* *}$ & $\mathrm{~L}^{*}$ & $\mathrm{~L}^{*}$ \\
\hline \multicolumn{6}{|c|}{ Fungicide-Nematicide } \\
\hline+ & 238 & 49.0 & 12.2 & 94.34 & 41.58 \\
\hline \multirow[t]{2}{*}{-} & 196 & 52.2 & 7.5 & 76.05 & 38.19 \\
\hline & $* *$ & $*$ & $*$ & $* * *$ & $* *$ \\
\hline \multicolumn{6}{|l|}{ Miticide } \\
\hline+ & 226 & 51.3 & 7.6 & 86.29 & 39.53 \\
\hline \multirow[t]{2}{*}{-} & 207 & 50.0 & 12.1 & 84.09 & 40.23 \\
\hline & $* * *$ & NS & $*$ & NS & NS \\
\hline \multicolumn{6}{|l|}{$\mathbf{N}$} \\
\hline Low (N1) & 202 & 52.7 & 12.7 & 81.67 & 38.65 \\
\hline Medium (N2) & 224 & 50.9 & 8.5 & 87.90 & 41.31 \\
\hline \multirow[t]{3}{*}{ High (N3) } & 224 & 48.3 & 8.3 & 86.00 & 39.70 \\
\hline & $\mathrm{L}^{* * *}$ & $\mathrm{~L}^{* * *}$ & $\mathbf{L}^{* * * *}$ & $\mathrm{~L}^{*}$ & \\
\hline & $\mathrm{Q}^{* *}$ & & & $Q^{*}$ & $\mathrm{Q}^{*}$ \\
\hline \multicolumn{6}{|l|}{ Gibberellin } \\
\hline+ & 217 & 50.2 & 10.2 & 85.73 & 39.79 \\
\hline \multirow[t]{2}{*}{-} & 215 & 51.0 & 9.5 & 84.65 & 39.98 \\
\hline & NS & NS & NS & NS & NS \\
\hline
\end{tabular}

$\overline{\mathrm{Ns}, *, * *, * * *}$ Nonsignificant or significant at $P \leq 0.05,0.01$, or 0.001 , respectively; $\mathrm{L}=$ linear; $\mathrm{Q}=$ quadratic.

Table 2. Interaction effects of irrigation and nitrogen on 'Navel' orange average yield percentage Grade 1, percentage size $\geq 25.4 \mathrm{~mm}$ fruit per tree, total returns (TRs) and partial net returns (PNRs), 1990.

\begin{tabular}{|c|c|c|c|c|c|c|}
\hline $\begin{array}{l}\text { Irrigation } \\
\text { (\% ETc) }\end{array}$ & $N^{2}$ & $\begin{array}{c}\text { Yield } \\
(\mathrm{kg} / \mathrm{tree})\end{array}$ & $\begin{array}{c}\text { Grade } \\
1 \\
(\%)\end{array}$ & $\begin{array}{c}\text { Size } \\
\geq 25.4 \\
(\%)\end{array}$ & $\begin{array}{c}\text { TRs } \\
(\$ / \text { tree })\end{array}$ & $\begin{array}{c}\text { PNRs } \\
\text { (\$/tree) }\end{array}$ \\
\hline \multirow[t]{3}{*}{120} & N1 & 205 & 50.2 & 19.2 & 85.48 & 40.84 \\
\hline & N2 & 234 & 51.6 & 11.7 & 96.10 & 46.08 \\
\hline & N3 & 240 & 49.8 & 11.4 & 96.18 & 45.74 \\
\hline \multirow[t]{3}{*}{100} & N1 & 195 & 54.6 & 11.2 & 79.58 & 37.63 \\
\hline & $\mathrm{N} 2$ & 220 & 52.1 & 9.1 & 88.50 & 41.82 \\
\hline & N3 & 220 & 50.6 & 9.9 & 87.63 & 40.76 \\
\hline \multirow[t]{3}{*}{80} & N1 & 205 & 53.2 & 7.8 & 79.95 & 37.48 \\
\hline & $\mathrm{N} 2$ & 217 & 49.0 & 4.7 & 79.09 & 36.01 \\
\hline & N3 & 212 & 44.6 & 3.7 & 74.20 & 32.60 \\
\hline \multicolumn{2}{|c|}{ Irrigation $\times \mathbf{N}$} & $\mathrm{L}^{* *}$ & $\mathbf{L}^{* * *}$ & NS & $\mathrm{L}^{* * *}$ & $\mathrm{~L}^{* * *}$ \\
\hline
\end{tabular}

${ }^{\mathrm{z}} \mathrm{N} 1=$ low, $\mathrm{N} 2$ = medium, N3 = high.

Ns,***,***Nonsignificant or significant at $P \leq 0.01$ or 0.001 , respectively; $\mathrm{L}$ $=$ linear. 
Table 3. Interaction effects of miticide and gibberellin on 'Navel' orange average yield, percentage Grade 1 , percentage size $\geq 25.4 \mathrm{~mm}$ fruit per tree, total returns (TRs), and partial net returns (PNRs), 1990.

\begin{tabular}{|c|c|c|c|c|c|c|}
\hline & & & Grade & Size & & \\
\hline Miticide & Gibberellin & $\begin{array}{c}\text { Yield } \\
(\mathrm{kg} / \mathrm{tree})\end{array}$ & $\begin{array}{c}1 \\
(\%)\end{array}$ & $\begin{array}{c}\geq 25.4 \\
(\%)\end{array}$ & $\begin{array}{c}\text { TRs } \\
\text { (\$/tree) }\end{array}$ & $\begin{array}{c}\text { PNRs } \\
\text { (\$/tree) }\end{array}$ \\
\hline+ & + & 231 & 50.7 & 9.1 & 89.24 & 40.84 \\
\hline+ & - & 222 & 51.8 & 6.0 & 83.34 & 38.23 \\
\hline- & + & 205 & 49.8 & 11.3 & 82.22 & 38.74 \\
\hline- & - & 210 & 50.2 & 13.0 & 85.96 & 41.73 \\
\hline \multicolumn{2}{|c|}{ Miticide $\times$ Gibberellin } & NS & NS & $*$ & $* *$ & $* *$ \\
\hline
\end{tabular}

cant decreases in percentages of Grade 1 fruit (Table 1). In the interactive effect, the deterioration in grade with higher amounts of $\mathrm{N}$ was virtually nonexistent with $120 \%$ ETc and was strongest with $80 \%$ ETc (highly significant irrigation linear $\times \mathrm{N}$ linear interaction) (Table 2).

Size. There was a significant increase in fruit size with increased irrigation level, but increased $\mathrm{N}$ resulted in decreases in percentage of large fruit. The interactive effect was not significant.

TRs and PNRs. TRs and PNRs showed a significant increase with increased irrigation (Table 1). TRs also increased significantly with increased $\mathrm{N}$, with $\mathrm{N} 2$ showing the highest TRs per tree. PNRs showed a significant increase for N2. In the irrigation $\times \mathrm{N}$ interactive effect, $120 \%$ ETc with N2 or N3 showed the best PNR (Table 2). N2 and N3 also showed similar TRs and PNRs with $100 \%$ ETc. This trend was reversed under $80 \%$ ETc, with N1 having the highest returns (highly significant irrigation linear $\times \mathrm{N}$ linear interaction).

\section{Miticide $\times$ gibberellin main and interactive effect}

Miticide significantly increased yield and significantly decreased fruit size (Table 1). Grade and returns were not affected. Productivity and returns were not affected by gibberellin. In the miticide $\times$ gibberellin interaction (Table 3 ), the decreased fruit size effect of miticide was ameliorated by gibberellin. The percentage of size $225.4 \mathrm{~mm}$ fruit per tree was reduced from $13 \%$ to $6 \%$ with miticide in the absence of gibberellin; but, with gibberellin, the corresponding reduction due to miticide was only $11.3 \%$ to $9.1 \%$. Although the main effects of miticide and gibberellin on TRs and PNRs were not significant, the interactions were significant. TRs and PNRs were higher with gibberellin if miticide had been applied but less in the absence of miticide, hence the significant interaction. PNRs were highest when neither miticide or gibberellin was used and next highest when both were used. Using just one or the other resulted in about equally low PNRs.

\section{Fungicide-nematicide main effect}

The fungicide-nematicide treatment did not show any significant interaction with any of the other treatments. The main effect showed a lower percentage of Grade 1 fruit than the nontreated trees, but yield, fruit size, TRs, and PNRs all showed a significant increase with fungicide-nematicide application.

\section{Impacts of water price changes on PNRs}

The PNRs of the three irrigation levels were tested for significance at increasing water prices. PNRs were significantly higher with increased irrigation, even when water prices increased (Table 4). Significant differences ceased when the water price exceeded $\$ 1.15 /$ ha-mm.

\section{Commercial packout data}

A commercial packout data analysis, which was done in combination of two treatments every year, showed that the 1987 irrigation $\mathrm{x}$ fungicide interaction resulted in increased PNRs with higher irrigation, even with increased water prices (Table 5). PNRs were also higher with fungicide application. For the $1988 \mathrm{~N} \times$ gibberellin interaction, N3 with or without gibberellin provided the highest return, followed by N2 without gibberellin. For the $1989 \mathrm{~N} \times$ miticide interaction, PNRs were highest for N3 without miticide, followed by $\mathrm{N} 2$ without miticide. These results are consistent with our 1990 statistical analysis.

\section{Discussion}

The biological productivity measures indicated that there existed statistical significance of interactive effects in some cases and only main effects with others. Furthermore, as several measures of productivity are involved in the evaluation of economic returns, knowledge of significant treatment effects in one or the other productivity characteristics would not provide a complete picture to the end user. For instance, increased $\mathrm{N}$ showed increased effect on yield but inverse effect on grade and size. It is not possible to know if a grower would be better off using N1 to get the best grade and size or a higher $\mathrm{N}$ level to increase yield without appropriate economic analysis. Such an analysis would incorporate the effect of prices on productivity and evaluate the impact of treatment costs on alternative use of inputs. According to our economic analysis, the highest PNR was obtained with N2.

The effects of two or more treatment interactions would be more complex. For instance, the irrigation $\times \mathrm{N}$ interaction required an evaluation of productivity and the accompanying returns, as well as cost effects of nine (three irrigation $\times$ three $N$ ) alternatives. Although yield increased with increased irrigation and $\mathrm{N}$, better grades were shown for $100 \%$ ETc at N1. The interaction showed no significant effect on size. We would need to answer whether 1) $100 \%$ ETc at N1 with the highest proportion of Grade 1 fruit together with the lower water and fertilizer cost would yield highest PNRs or 2) the yield increase of $120 \%$ ETc at N3 would offset the grade and cost benefit gained at $100 \%$ ETc or even more if $80 \%$ ETc could outperform the others through minimization of water costs. Therefore, conclusive recommendations would have been difficult on the overall benefits of treatments and interactions without the detailed economic analysis. In this study, we have illustrated the importance of an economic approach to evaluate the level and interaction of inputs to maximize grower returns.

The 1990 economic analysis of the interactive practices showed that a significantly higher grower PNR was obtained from the treatment with $120 \%$ ETc, N2 or N3, +F-N, $-\mathrm{M}$, and $-\mathrm{G}$ (high irrigation, $\mathrm{N} 2$ or $\mathrm{N} 3$, fungicide-nematicide, and no miticide and gibberellin) than from any other treatment. The next highest grower PNR was the same treatments except with the use of miticide and gibberellin. These results were consistent with the economic returns estimated from the commercial packout data that showed highest PNRs from $120 \%$ ETc; $+\mathrm{F}$ in 1987 ; N3, $+\mathrm{G}$ or N3, -G in 1988; and N3, -M, or N2, -M in 1989.

In California, where irrigation is essential for crop production, agricultural water availability and prices are important issues that will influence future cropping patterns. Therefore, the combination of treatments that provide maximum return may vary as water cost varies. The impact of variable water prices on PNRs and the implications regarding irrigation management indicated that the highest ETc was beneficial, even if the price of water rose to $\$ 2.30$ / ha-mm (Table 4). Water prices in the central California citrus 
growing region were generally under $\$ 1.15 /$ ha-mm. Therefore, applying water at $120 \%$ ETc is acceptable, given the availability of water. Applying water, however, needs to be considered in combination with $\mathrm{N}$ use. The $120 \%$ ETc can be used with N3. If water availability were to be restricted to $100 \%$ ETc, growers can use N2

Table 4. The effect of water price changes on partial net returns (PNRs) of 'Navel' oranges.

\begin{tabular}{|c|c|c|c|c|}
\hline \multirow{2}{*}{$\begin{array}{l}\text { Water } \\
\text { price } \\
(\$ / \text { ha-mm) }\end{array}$} & \multicolumn{3}{|c|}{ Irrigation treatment (\% ETc) } & \multirow[b]{2}{*}{ Significance } \\
\hline & 120 & 100 & 80 & \\
\hline \multicolumn{5}{|c|}{ PNR $(\$ /$ tree $)$} \\
\hline 0.30 & 44.22 & 40.07 & 35.36 & $\mathrm{~L}^{*}$ \\
\hline 0.50 & 43.60 & 39.56 & 34.95 & $\mathrm{~L}^{*}$ \\
\hline 0.70 & 42.79 & 38.88 & 34.41 & $\mathrm{~L}^{*}$ \\
\hline 1.00 & 41.98 & 38.21 & 33.87 & $\mathrm{~L}^{*}$ \\
\hline 1.20 & 41.18 & 37.53 & 33.33 & $\mathrm{~L}^{*}$ \\
\hline 1.50 & 40.37 & 36.86 & 32.78 & $\mathrm{~L}^{*}$ \\
\hline 1.70 & 39.56 & 36.19 & 32.24 & $\mathrm{~L}^{*}$ \\
\hline 1.90 & 38.75 & 35.51 & 31.70 & $\mathbf{L}^{*}$ \\
\hline 2.20 & 37.94 & 34.84 & 31.16 & $\mathrm{~L}^{*}$ \\
\hline 2.40 & 37.13 & 34.16 & 30.62 & NS \\
\hline 2.70 & 36.32 & 33.49 & 30.08 & NS \\
\hline 2.90 & 35.51 & 32.82 & 29.53 & NS \\
\hline
\end{tabular}

Table 5. Partial net returns (PNRs) per tree for treatment combination.

\begin{tabular}{|c|c|c|c|c|}
\hline \multirow[b]{2}{*}{ Treatment } & \multirow[b]{2}{*}{$\begin{array}{c}\text { Yield } \\
\text { (kg/tree) }\end{array}$} & \multicolumn{3}{|c|}{ PNR } \\
\hline & & $\begin{array}{c}(\$ / \text { tree @ } \\
\$ .30 / \text { ha-mm) }\end{array}$ & $\begin{array}{c}(\$ / \text { tree } @ \\
\$ 1.20 / \text { ha-mm }) \$\end{array}$ & $\begin{array}{c}(\$ / \text { tree @ } \\
2.20 \text { ha-mm) }\end{array}$ \\
\hline \multicolumn{5}{|c|}{1987} \\
\hline $80 \%$ ETc F- & 108 & 20.73 & 18.70 & 16.54 \\
\hline $80 \% \mathrm{ETc} F+$ & 133 & 24.08 & 22.04 & 19.88 \\
\hline $100 \%$ ETc F- & 130 & 30.41 & 27.87 & 25.17 \\
\hline $100 \% \mathrm{ETc} F+$ & 145 & 32.70 & 30.16 & 27.46 \\
\hline $120 \%$ ETc F- & 147 & 35.75 & 32.71 & 29.47 \\
\hline \multicolumn{5}{|c|}{1988} \\
\hline N1 G- & 197 & 27.85 & 25.32 & 22.62 \\
\hline $\mathrm{N} 1 \mathrm{G}+$ & 182 & 25.75 & 23.21 & 20.51 \\
\hline N2 G- & 225 & 31.78 & 29.24 & 26.54 \\
\hline $\mathrm{N} 2 \mathrm{G}+$ & 217 & 28.97 & 26.43 & 23.73 \\
\hline N3 G- & 237 & 35.84 & 33.30 & 30.60 \\
\hline N3 G+ & \multicolumn{3}{|c|}{1989} & 31.13 \\
\hline N1 M- & 110 & 13.43 & 10.89 & 8.19 \\
\hline N1 M+ & 131 & 15.58 & 13.05 & 10.35 \\
\hline N2 M- & 141 & 19.97 & 17.44 & 14.74 \\
\hline $\mathrm{N} 2 \mathrm{M}+$ & 156 & 17.21 & 14.67 & 11.97 \\
\hline N3 M- & 156 & 21.80 & 19.26 & 16.56 \\
\hline N3 M+ & 160 & 17.74 & 15.20 & 12.50 \\
\hline \multicolumn{5}{|c|}{1990} \\
\hline F- M- & 188 & 37.84 & 35.30 & 32.60 \\
\hline $\mathrm{F}-\mathrm{M}+$ & 203 & 36.89 & 34.35 & 31.65 \\
\hline $\mathrm{F}+\mathrm{M}-$ & 231 & 42.94 & 40.41 & 37.71 \\
\hline $\mathrm{F}+\mathrm{M}+$ & 252 & 42.10 & 39.56 & 36.86 \\
\hline
\end{tabular}

${ }^{\text {ZIrrigation level ( } \% \text { ETc): low }=80 \% \text {, medium }=100 \%, \text { high }=120 \% . \mathrm{N}}$ rate: $\mathrm{N} 1=$ low, $\mathrm{N} 2=$ medium, $\mathrm{N} 3=$ high. $\mathrm{F}-\mathrm{N}=$ fungicide-nematicide, $\mathrm{G}=$ gibberellin, $\mathrm{M}=$ miticide; with (+) or without $(-)$. or N3 to maximize returns. If restriction extends to the extent of allowing only $80 \%$ ETc irrigation, growers should use N1 to maximize returns.

In light of the biological analysis, the following considerations should be noted. Fruit harvested from trees receiving greater amounts of water had a higher soluble solids concentration and percentage juice content (Arpaia and Eaks, 1990). Although it has been a general concern among California citrus growers that overirrigation would lead to root health problems by encouraging phytophthora rot, we have not seen any in this experiment. However, those trees receiving $80 \%$ ETc, even though they had yields equal to that of $100 \%$ ETc, produced fruit of inferior quality and that were significantly smaller. Also, partial defoliation has occurred in trees of $80 \%$ ETc (Menge et al., 1990).

The costs of fungicides and nematicides also concern growers. These costs, reaching up to $\$ 1500 /$ ha, are the highest cost treatments in orange production. However, trees receiving fungicidenematicide produced higher PNRs because of increased yield, grade, and fruit size.

The application of miticides was included in the second highest returning treatment combination. The following points, however, should be noted. First, miticide increased yield ( 2 of the 3 years), but, it seemed to reduce fruit size. Thus, in the end, the economic analysis showed no significant differences for treatments with or without miticide in this study and in another 4-year study (Hare et al., 1992) that evaluated the impact of the citrus red mite (Acari: Tetranychidae) on 'Navel' orange crop value. We found that withholding acaricides (miticide treatment) suppressed yields on trees more in the N1 than in the N2 or N3 plots. Also, the effect of miticide was examined in isolation from other arthropod pests of citrus, because the grove received uniform treatments for the others, when needed. Given that miticides are detrimental to predaceous mites implicated in thrips suppression, the indirect effects of miticides on crop value also may need to be reevaluated via the effects of increasing the need for costly thrips sprays and compared to the returns that will be forgone by withholding acaricides. In light of these observations, growers with wellmaintained groves are encouraged to tolerate a citrus red mite population in excess of the old threshold of two adult females per leaf, thereby minimizing acaricide treatments and preserving populations of predaceous mites and other natural enemies that might control other, more important citrus insects.

The effect of gibberellin in improving TRs and PNRs was significant only when it was used with miticides. Therefore, its use should be considered in conjunction with the need for miticides.

\section{Literature Cited}

Arpaia, M.L. and I.L. Eaks. 1990. The effect of cultural practices on the postharvest response of 'Navel' orange. 23rd Intl. Soc. Hort. Sci., Firenze, Italy, 27 Aug.-1 Sept. Abstr. 2494:678.

California-Arizona Citrus League. 1990. Navel Grower Cost Survey for the 1988-89, 1989-90, and 1990-91 seasons. California-Arizona Citrus League California Dept. of Food and Agr., California Agr. Stat. Serv. Coggins, C.W., Jr., and H.Z. Hield. 1968. Plant-growth regulators, p. 371389. In: W. Reuther, L.D. Batchelor and H.J. Webber (eds.). The citrus industry. vol. 2. Univ. of California, Div. of Agr. Sci., Berkeley.

Embleton, T.W., W.W. Jones, C. Pallares, and R.G. Platt. 1978. Effects of fertilization of citrus on fruit quality and ground water nitrate-pollution potential. Proc. Intl. Soc. Citricult. p. 280-285.

Garabedian, S. and S.D. Van Gundy. 1985. Effects of nonfumigant nematicides applied through low-pressure drip irrigation on control of Meloidogyne incognita on tomatoes. Plant Dis. 69:138-140.

Hare, J.D., J.G. Morse, J.L. Menge, J.E. Pehrson, C.W. Coggins, Jr., T.W. Embleton, W.M. Jarrell, and J.L. Meyer. 1989a. Population responses of 
the citrus red mite and citrus thrips to 'Navel' orange cultural practices. Environ. Entomol. 18:(3):481-488.

Hare, J.D., J.E. Pehrson, T. Clemens, J.L. Menge, C.W. Coggins, Jr., T.W. Embleton, and J.L. Meyer. 1990. Effects of managing citrus red mite (Acari: Tetranychidae) and cultural practices on total yield, fruit size, and crop value of 'Navel' orange. J. Econ. Entomol. 83(3):976-984.

Hare, J.D., J.E. Pehrson, T. Clemens, J.A. Menge, C.W. Coggins, Jr., T.W. Embleton, and J.L. Meyer. 1992. Effects of citrus red mite (Acari: Tetranychidae) and cultural practices on total yield, fruit size, and crop value of 'Navel' orange: Years 3 and 4. J. Econ. Entomol. 85(2)486-495.

Hare, J.D., J.E. Pehrson, T. Clemens, and R.R. Youngman. 1989b. Combined effects of differential irrigation and feeding injury by the citrus red mite (Acari: Tetranychidae) on gas exchange of orange leaves. J. Econ. Entomol. 82(1):204-208.
Hoare, E.R. and H.D. Barrs. 1974. Water relations and photosynthesis amongst horticultural species as affected by simulated soil water stress, p. 321-334. In: R. Antoszewski, L. Harrison, and J. Nowosielski (eds.). Proc. 19th Intl. Hort. Cong. vol. 3. Warsaw, Poland.

Marsh, A.W. 1973. Irrigation, p. 230-279. In: W. Reuther (ed.). The citrus industry. vol. 3. Univ. of California Div. of Agr. Sci., Berkeley.

Menge, J., J. Morse, D. Hare, C. Coggins, J. Pehrson, J. Meyer, T. Embleton, S. Van Gundy, A. Dodds, M.L. Arpaia, E. Takele, C. Adams, A. Strawn, E. Pond, and D. Atkin. 1990. Integrated crop management increases citrus growth and yields. Calif. Agr. 44(4):11-12.

O'Connell, N., J. Maranto, M. Freeman J. Pehrson, and E. Yeary. 1987.1987 Grange production management. Univ. of California Coop. Ext. Serv.

Takele, E. and J. Pehrson. 1989. Cost of 'Navel' orange production at McKellar Farms. Univ. of California Coop. Ext. Serv. 